\title{
Understanding Culture: A Literature Review Comparing Three Cultural Pedagogies
}

\author{
Tabitha Kidwell \\ University of Maryland, College Park \\ tabithakidwell@gmail.com \\ DOI: http://dx.doi.org/10.18326/rgt.v10i2.221-233
}

\begin{abstract}
Submission
Track:

ENGLISH ABSTRACT

Received:

$23 / 10 / 2017$

Culture is an integral part of language study, but the field has yet to

Final Revision:

put forward a coherent theoretical argument for how culture can or

$04 / 12 / 2017$ should be incorporated in language education. In an effort to remedy this situation, this paper reviews literature on the teaching of

Available online: culture, drawing on Larzén's (2005) identification of three pedagogies used to teach about culture within the language classroom: through a pedagogy of information, a pedagogy of $06 / 12 / 2017$ preparation, and a pedagogy of encounter. The pedagogy of information takes a cognitive orientation, framing culture as factual knowledge, with a focus on the teacher as the transmitter of knowledge. The pedagogy of preparation portrays culture as skills, and aims to help students develop the sociocultural, pragmatic, and strategic competence necessary for interactions with native speakers. The pedagogy of encounter takes an intercultural approach, with an affective orientation, and aims to help students develop tolerance, empathy, and an awareness of their own and others' perspectives, and the emergent nature of culture. Using these three pedagogies as a conceptual framework, this paper reviews scholarship in support and critique of each type of cultural teaching. Because each of these three pedagogies continues to be used in various contexts worldwide, a clear understanding of the beliefs systems underpinning the belief systems of teachers and learners is essential.
\end{abstract}

Keywords: Culture; Language Teaching; Methodologies.

\section{INDONESIAN ABSTRACT}

Budaya merupakan bagian integral dari studi bahasa, namun khalayak belum mengemukakan argumen teoritis yang koheren untuk 
bagaimana budaya dapat atau harus digabungkan dalam pendidikan bahasa. Dalam upaya memperbaiki situasi ini, makalah ini mengulas literatur tentang ajaran budaya, dengan mengacu pada identifikasi tiga pedagogi Larzén (2005) yang digunakan untuk mengajarkan tentang budaya di dalam kelas bahasa: melalui pedagogi informasi, pedagogi persiapan, dan pedagogi perjumpaan Pedagogi informasi mengambil orientasi kognitif, membingkai budaya sebagai pengetahuan faktual, dengan fokus pada guru sebagai pemancar pengetahuan. Pedagogi persiapan menggambarkan budaya sebagai keterampilan, dan bertujuan untuk membantu siswa mengembangkan kompetensi sosiokultural, pragmatis, dan strategis yang diperlukan untuk interaksi dengan penutur asli. Pedagogi pertemuan mengambil pendekatan antar budaya, dengan orientasi afektif, dan bertujuan untuk membantu siswa mengembangkan toleransi, empati, dan kesadaran akan perspektif mereka sendiri dan orang lain, dan sifat budaya yang muncul. Dengan menggunakan ketiga pedagogi ini sebagai kerangka konseptual, makalah ini mengulas pustaka untuk mendukung dan mengkritik setiap jenis pengajaran budaya. Karena masing-masing dari ketiga pedagogi ini terus digunakan dalam berbagai konteks di seluruh dunia, pemahaman yang jelas tentang sistem kepercayaan yang mendasari sistem kepercayaan guru dan pelajar sangat penting.

Kata kunci: Budaya; Pengajaran Bahasa; Metodologi.

\section{INTRODUCTION}

The emergence of English as a global language means that English is increasingly the medium of interaction for cross-cultural exchanges. By teaching English, teachers around the world are preparing students for encounters with people from different cultures - both monolingual speakers of English and multilingual speakers from various backgrounds. Successful communication will require cultural proficiency in addition to language proficiency. To support students' participation in the $21^{\text {st }}$ century knowledge economy, English teachers must therefore be prepared to attend to the cultural aspects of learning a foreign language. Without professional preparation to do so, teachers are likely to teach as they were taught, prioritizing linguistic objectives and perpetuating outdated modes of curriculum and pedagogy. One essential aspect of that professional preparation is an understanding of the nature of culture, and the ability to define the concept. 
Culture is a central part of language study because culture and language are inextricably linked - language is both an integral part of the construction of culture and the way culture is expressed (Agar, 1994, Kramsch, 1993). Cultural competency is essential to language learning because of culture's impact on everyday interactions and on norms of speaking and behaving (Hymes, 1972). Language classrooms, therefore, are almost always sites of cultural contact. Language teachers act as "cultural workers" (Giroux, 2005, p. 71), or "go-betweens" (Kramsch, 2004, p. 37) because they are asked to socialize students into new cultural and linguistic practices and help them develop "intercultural, cognitive, social and affective connections" (Duff \& Uchida, 1997, p. 476). Language teachers must not only teach language - they must also help students understand the nature of culture and culture's impact on language, communication, and interaction.

\section{CULTURAL PEDAGOGIES}

Culture, therefore, is one of the most important concepts in the field of language teaching. In the English teaching context, for instance, Atkinson (1999) notes, "except for language, learning, and teaching, there is no more important concept in the field of TESOL than culture" (p. 625). Nevertheless, scholars vary in their definitions of culture and the role culture should play in language teaching. These differing understandings of culture have contributed to "a certain degree of ambiguity among language teachers regarding 'teaching culture" (Rantz \& Horan, 2005). In one of the few studies to explicitly examine language teachers' beliefs about culture, Larzén's (2005) found that language teachers' cultural understandings, objectives, and practices conformed to one of three approaches, which she called the pedagogy of information, the pedagogy of preparation, and the pedagogy of encounter. In this paper, I draw on Larzén's (2005) framework to discuss various language teaching scholars' views of culture, and how their views have evolved over time. See figure 1 for an overview of Larzén's (2005) cultural pedagogies. 
Figure 1: Continuum of Cultural Pedagogies (drawing from Larzén, 2005)

\begin{tabular}{|c|c|c|c|}
\hline & $\begin{array}{l}\text { Pedagogy of } \\
\text { Information }\end{array}$ & Pedagogy of Preparation & $\begin{array}{l}\text { Pedagogy of } \\
\text { Encounter }\end{array}$ \\
\hline Aims to Impart... & Facts & Skills & Perspectives \\
\hline $\begin{array}{ll}\text { Aims } & \text { to } \\
\text { Develop...* } & \end{array}$ & $\begin{array}{l}\text { Linguistic } \\
\text { Competence }\end{array}$ & $\begin{array}{l}\text { Communicative } \\
\text { Competence }\end{array}$ & $\begin{array}{l}\text { Intercultural } \\
\text { Competence }\end{array}$ \\
\hline Orientation & Cognitive & Action-based & Affective \\
\hline Goal & $\begin{array}{l}\text { Provide } \\
\text { background } \\
\text { knowledge }\end{array}$ & $\begin{array}{l}\text { Prepare for interactions } \\
\text { with native speakers }\end{array}$ & $\begin{array}{l}\text { Cultivate tolerance } \\
\text { and empathy }\end{array}$ \\
\hline Focus & Teacher & Teacher and student & Student \\
\hline View of Culture* & Knowledge & $\begin{array}{l}\text { Sociocultural, Pragmatic } \\
\text { \& Strategic Competence }\end{array}$ & Social Process \\
\hline $\begin{array}{l}\text { Analogous View of } \\
\text { Language* }\end{array}$ & Code & $\begin{array}{l}\text { Communicative } \\
\text { Competence }\end{array}$ & Semiotic Process \\
\hline
\end{tabular}

*An asterisk denotes information I have added to Larzén's (2005) findings.

\section{Pedagogy of information}

The pedagogy of information takes a cognitive orientation and is typically paired with a focus on linguistic competence. In this pedagogy, culture is presented as factual knowledge. This type of teaching was prevalent during the grammar translation era, when language was primarily seen as a code. Throughout much of the history of language teaching, culture has been seen as background knowledge to be provided by the teacher and acquired by students. From the 1800 s to mid 1900 s, the grammar translation approach was the primary language teaching approach, and the development of students' cultural knowledge was thought to occur through their exposure to literature in the target language. Indeed, students' ability to understand texts in the target language was considered the central goal of language instruction 
(Byrd, Hlas, Watzke \& Valencia, 2011). Culture instruction focused on a group's conventionally praised cultural achievements, knowledge of which contributes to a person's status as a "cultured" individual. As language teaching evolved, the increased popularity of behaviorist psychology, influenced by the work of B.F. Skinner (e.g., Skinner, 1953), led to the implementation of the audio-lingual method in the 1950s and 60s. Within this model of language teaching, cultural knowledge was seen as necessary to avoid social blunders; because of the audio-lingual method's behaviorist underpinnings, culture was presented as factual knowledge that students could master through patterned drill activities, as with linguistic knowledge (Byrd et al, 2011). Though culture came to be seen as a skill or competency with the advent of communicative language teaching approach in the 1980s, in many contexts, culture continued (and continues) to be primarily seen cognitively - as knowledge to be acquired. This view of culture continues to be the traditional approach taken by language teachers, and it is an approach that has been supported by published teaching materials, curricula, and standards documents.

\section{Critiques of the pedagogy of information}

The knowledge-based view of culture has been criticized in recent years for several reasons. First, the focus on the transmission of knowledge places teachers in the central, active role, with students positioned as passive recipients of knowledge. This style of education has been criticized by Freire (1970) and Illich (1971) as a dehumanizing pedagogy that that perpetuates systems of power and oppression. Freire (1970) describes this pedagogical system as the "banking concept" of education, where students are seen as empty bank accounts, devoid of prior knowledge, in which teachers can make deposits through knowledge transmission. A knowledge-based view of cultural learning is consistent with a behaviorist view of teaching that has been challenged by constructivist models (e.g., Smith, 1971), which view learning as the integration of new knowledge with existing knowledge through learners' active involvement in the learning process, and by social constructivist models (e.g., Vygotsky, 1978), which emphasize the active co-construction of knowledge through social interaction.

Additionally, though teachers operating under a knowledge-based view of culture may intend to focus on the products, practices and perspectives (sometimes called the "three Ps") 
of the target culture, there is a tendency to reduce instructional content to "the four Fs": Food, Fashion, Festivals and Folklore (Banks, 2002). This trivialized definition of culture does not take into account the complex nature of culture and tends to focus on exoticism, stereotypes, and an exaggerated view of difference. By focusing on the differences across and among cultures, language teachers tend to avoid examination of difference within cultures and miss the opportunity to engage in critical dialogue about issues of racism and power. Often, the culture of study is "otherized" in comparison with the home culture, and at times even stands in as a proxy for race (Holliday, 2009; Lee, 2014). In this approach, students are often implicitly encouraged to develop binary views of culture or even a deficit view of other cultures because they are not encouraged to examine and become aware of their own cultural assumptions and stereotypes (Banks, 1994).

Lastly, by focusing on the specific culture of a target country, this view adopts a nation-state view of culture and portrays culture as homogenous, static, and (often) monolingual. Because the essentializing nation-state view of culture also applies to understandings of culture as skills or competencies, I will discuss this critique more in detail following the next section.

\section{Pedagogy of preparation}

The pedagogy of preparation takes an action-based orientation and is typically paired with a focus on communicative competence. Culture was cast as an aspect of communicative competence during the advent of the communicative language teaching method. As the field of educational psychology moved away from transmission-based and behavioral models of learning, the field of language pedagogy came to favor communicative language teaching over grammar-translation and audiolingual methods. Influenced by these shifts, culture came to be seen not only as knowledge to be transmitted or acquired, but also as an essential aspect of language competence. Within this view, whether speakers possess cultural knowledge is less important than their ability to act upon (or enact) that cultural knowledge to support successful communication. Neither cultural nor linguistic knowledge are as important as a language user's ability to use that knowledge to engage in communication.

In this view, culture - like language - is a skill to be drawn on to support effective communication. According to Hymes (1972), language learning does not simply require 
morphological and syntactical knowledge - it also requires the ability to use the language appropriately in the cultural context. Language users need sociocultural knowledge knowing when to speak, when not to speak, whom to speak with, and how to speak - in addition to linguistic competence. The importance of culture as a key feature of language proficiency became increasingly clear through the work of Canale and Swain (1980), who built on Hymes' model by identifying three components of communicative competence: grammatical (the syntactic, lexical, morphological, and phonological features of the language); sociolinguistic (the social rules of language use); and strategic (communication strategies to handle breakdowns in communication). Canale (1983) added a fourth component: discourse, the extended use of language in context. Because social rules, appropriate communication strategies, and organizational patterns are impacted by culturally bound norms, values, beliefs, and behavior patterns, culture is an essential element of the sociolinguistic, strategic, and discourse competencies. By extension, the teaching of culture is an essential element of language instruction that takes communicative competence as its goal.

\section{Critiques of pedagogy of preparation}

A critique of the pedagogy of preparation (as well as of the pedagogy of information, discussed above) is that the culture that is focused on is often that of a particular nation-state for instance, British culture, French culture, or Argentinean culture. The major critique of this view is that by focusing on the specific culture of a target country, this view adopts a nationstate view of culture and portrays culture as homogenous, static, and (often) monolingual. Though national and ethnic identities are important, scholars such as Kumaravadivelu (2008) and Risager (2007) argue that language educators' adherence to nation-based understandings of culture is overly simplistic. Nation-based approaches have been critiqued as essentializing differences between nations while denying differences within nations (Harklau, 1999; Kubota, 1999). Scholars argue that language teachers should adopt a more nuanced understanding that is not dictated by geographic borders to better serve students' needs in the era of globalization. Risager (2007), for instance, calls for "a transnational paradigm," which would reduce the field's dependence on membership in a certain nation-state as the defining feature of an individual's culture. 
An additional important critique of the nation-state model is its adherence to a nativespeaker norm. Alptekin (2002) questions the validity of a pedagogic model based on a native speaker-based notion of communicative competence because the model is based on a utopian, unrealistic understanding of "the native speaker," and on a monolithic perception of "the native speaker's" language and culture. Many scholars join in these critiques of "native speakerism" and adherence to an idealized native speaker model (i.e., Cook, 1999; Jenkins, 2006; Pennycook, 1999). These critiques have led scholars to advocate for the inclusion of culture in language teaching in order to help students develop communicative skills across and within a variety of cultures, not merely in accordance with native speaker norms. This approach can be considered "pedagogy of encounter," and is discussed in the following section.

\section{Pedagogy of encounter}

The pedagogy of encounter takes an affective orientation and is typically paired with a focus on intercultural competence. Now that scholars increasingly view language as a semiotic process, the teaching of culture is intended to help students develop intercultural communicative skills. In this model, the pedagogical model is not native speakers, but multilinguals with intercultural knowledge and skills that allow them to communicate effectively with others across cultural and linguistic differences (Alptekin, 2002; Hyde, 1998, Kramsch, 1995). Students need to develop skills as "multilingual communicators," which extend beyond mastery of a single cultural code (Baker, 2011 p. 63). In developing the competencies necessary for students to navigate the "borders" between cultures, it is important that teachers validate students' cultures while also developing their willingness to engage with others.

Developing students' intercultural communicative competence requires language teachers to focus not only on the local culture or the target culture, but also on the culture embodied in learners' emergent, variant cultural understandings. Kramsch (1996) refers to the site of cultural learning as a "third place" and suggests that "language teachers focus less on seemingly fixed, stable cultural entities and identities on both sides of national borders, and more on the shifting and emerging third place of the language learners themselves (Kramsch, 1996, p. 9). In this third place, learners are positioned at the "intersection of multiple social roles and individual choices," and are able to develop a richer understanding of the multifaceted nature of culture (Kramsch, 1993, p. 234). A focus on these sites can be powerful 
because it raises issues of power, conflict, and social justice. Language classrooms can be places where learners engage with these important issues, but teachers must be willing and prepared to act as "go-betweens" who actively support students' engagement with these complex issues (Kramsch, 2004, p. 37)

\section{Critiques of pedagogy of encounter}

Though the pedagogy of encounter, with its focus on development of intercultural communicative competence, is viewed by many scholars as the preferred approach to the teaching of culture in language classrooms, this approach is not universally accepted. In recent years, scholars in various periphery countries such as Tanzania (Biswalo, 2015), Bahrain (Mawoda, 2011), and Indonesia (Gandana, 2014; Siregar, 2015) have similarly questioned the appropriacy of intercultural teaching methods within their contexts. Additionally, scholars in several Muslim majority countries have found challenges related to a cultural divide between the local culture and the "west." In Indonesia, Gandana (2014) found that EFL teachers saw "the west" as both the object of desire and resentment, and that teachers' ability to teach inter-culturally was hampered by the rigid hierarchy inherent in their own culture. In other words, individual teachers did not feel that they could question a curriculum that adhered to a knowledge-based view of culture that portrayed "western culture" somewhat monolithically. Similarly, Siregar (2015) found that university EFL teachers in Indonesia encounter deeply ingrained essentialist beliefs about both Indonesian culture and foreign cultures among their students, which implies an "us-them" view of culture and cultural difference that has little room for variance or nuance. In Brunei, Elgar (2011) found that, while English skills are highly sought after, the global dominance of English is also a source of resentment, and there were worries that increasingly widespread English skills would threaten the nation's cultural values. In Iran, Zabetipour and Baghi (2015) reported a fear that EFL learners would be "at risk of an emerging new identity that tries to replace Iranian sociocultural and religious identity with a new Western one” (p. 330), thus illustrating concerns that English teaching would go hand-in-hand with cultural imperialism. Given these concerns, there is a need for research in Muslim and non-Western contexts that examines the potential implementation of language teaching with the aim of intercultural communicative competence. 


\section{CONCLUSION}

The body of literature on the teaching of culture reviewed above reveals three ways to teach about culture within the language classroom: through a pedagogy of information, a pedagogy of preparation, and a pedagogy of encounter. The pedagogy of information takes a cognitive orientation, framing culture as factual knowledge, with a focus on the teacher as the transmitter of knowledge. The pedagogy of preparation portrays culture as skills, and aims to help students develop the sociocultural, pragmatic, and strategic competence necessary for interactions with native speakers. The pedagogy of encounter takes an intercultural approach, with an affective orientation, and aims to help students develop tolerance, empathy, and an awareness of their own and others' perspectives, and the emergent nature of culture.

Though scholarly discussion of these three pedagogies emerged chronologically, it should not be assumed that the pedagogy of encounter is the predominant model in use currently. Rather, all three pedagogies can likely be found in various contexts, and even within the practice of a single teacher over the course of a single lesson. Because the pedagogy of information was long the prevalent method, many language teachers were exposed to it through their own language learning experiences, and continue to adhere to that approach. Additionally, because the pedagogy of preparation was the predominant approach advocated by teacher educators and language education scholars since the 1980s, many current practicing teachers were exposed to the idea of communicative competence during their teacher preparation programs; indeed, in many contexts, they continue to be exposed to these concepts.

Because each of these three pedagogies continues to be used in various contexts worldwide, it is important to have an understanding of each when observing language teachers or speaking to them about their practice. Identifying which pedagogies teachers are drawing from in a given lesson allows for a clearer understand of the rationales underlying the decisions they make about teaching culture. As English comes to be used as an International language, it will become increasingly important to design education research studies with a clear understanding of the beliefs systems underpinning the belief systems of teachers and learners - particularly when undertaking research in under-researched contexts in nonWestern countries. 


\section{REFERENCES}

Agar, M. (1994). Language shock: The culture in everyday conversations. New York, NY: Morrow.

Alptekin, C. (2002). Towards intercultural communicative competence in ELT. ELT Journal, $56(1), 57-64$.

Atkinson, D. (1999). TESOL and culture. TESOL Quarterly, 33(4), 625-654.

Baker, W. (2011). From cultural awareness to intercultural awareness: culture in ELT. ELT Journal, 66(1), 62-70. http://doi.org/10.1093/elt/ccr017

Banks, J. A. 1994. Multiethnic Education: Theory and Practice. Needham Heights, MA: Allyn \& Bacon.

Banks, J. (2002) Cultural diversity and education: Foundations, curriculum, and teaching (4th ed). New York, NY: John Wiley and Sons.

Biswalo, U. P. (2015). Exploring intercultural communicative competence among English language teachers in secondary schools in Tanzania: A postcolonial perspective. (Unpublished doctoral dissertation). Victoria University of Wellington, Wellington, New Zealand.

Byrd, D. R., Hlas, A. C., Watzke, J., \& Valencia, M. F. M. (2011). An examination of culture knowledge: A study of L2 teachers" and teacher educators" beliefs and practices. Foreign Language Annals, 44(1), 4-39.

Canale, M. (1983.) 'From communicative competence to communicative language pedagogy' in J. C. Richards and R. W. Schmidt (eds.). Language and communication. London, UK: Longman.

Canale, M., \& Swain, M. (1980). Theoretical bases of communicative approaches to second language teaching and testing. Applied Linguistics, 1(1), 1-47.

Cook, V. (1999). Going beyond the native speaker in language teaching. TESOL Quarterly, 33(2), 185-209.

Duff, P., \& Uchida, Y. (1997). The negotiation of teachers' sociocultural identities and practices in postsecondary EFL classrooms. TESOL Quarterly, 31(3), 451-486.

Elgar, A. G. (2011). Culture Through Literature in Foreign Language Teaching. In J. Arabski, (Ed.), Aspects of culture in second language acquisition and foreign language learning (pp. 139-147). Berlin, Germany: Springer. http://doi.org/10.1007/978-3-64220201-8_11

Freire, P. (1970). Pedagogy of the oppressed. New York, NY: Herder and Herder. 
Gandana, I. (2014). ELT, interculturality, and teacher identity: An inquiry into Indonesian university teachers' beliefs and practices. (Unpublished doctoral dissertation). Monash University, Melbourne, Australia.

Giroux, H. A. (2005). Border crossings: Cultural workers and the politics of education ( $2^{\text {nd }}$ ed.). New York, NY: Routledge.

Harklau, L. (1999). Representing culture in the ESL writing classroom. In E. Hinkel (Ed.), Culture in second language teaching and learning (pp. 109-130). Cambridge, UK: Cambridge University Press.

Holliday, A. (1999). Small cultures. Applied Linguistics, 20(2), 237-264.

Hyde, M. (1998) Intercultural competence in English language education. Modern English Teacher 7(2) 7-11.

Hymes, D.H. (1972). 'On communicative competence' in J. Pride and J. Holmes (Eds.). Sociolinguistics (pp. 269-293). Harmondsworth, UK: Penguin.

Illich, I. (1971). Deschooling society. New York, NY: Harper \& Row.

Jenkins, J. (2006). Current on perspectives teaching world Englishes and English as a lingua franca. TESOL Quarterly, 40(1), 157-181.

Kramsch, C. (1993). Context and culture in language teaching. Oxford, UK: Oxford University Press.

Kramsch, C. (1995) The applied linguist and the foreign language teacher: Can they talk to each other? In G. Cook, (Ed.) Principle \& practice in applied linguistics: Studies in honour of H.G. Widdowson (pp. 43-56). Oxford, UK: Oxford University Press.

Kramsch, C. (1996). The cultural component of language teaching. Language, Culture and Curriculum, 8(2), 83-92. http://doi.org/10.1080/07908319509525192

Kramsch, C. (2004). The language teacher as go-between. Education and Democracy, 13(3), $37-60$.

Kubota, R. (1999). Japanese culture constructed by discourses: Implications for applied linguistics research and ELT. TESOL Quarterly, 33(1), 9-35.

Kumaravadivelu, B. (2008). Cultural globalization and language education. New Haven, CT: Yale University Press.

Larzén, E. (2005). In pursuit of an intercultural dimension in EFL teaching: Exploring cognitions among Finland-Swedish comprehensive school teachers. Biskopsgtan, Finland: Abo Akedemi University Press.

Lee, E. (2014). Doing culture, doing race: Everyday discourses of 'culture' and 'cultural difference' in the English as a second language classroom. Journal of Multilingual and 
Multicultural Development, $\quad 36(1), \quad 80-93$. http://doi.org/10.1080/01434632.2014.892503

Mawoda, K. R. A. (2011). Exploring secondary teachers' perceptions towards teaching intercultural competence in Bahrain in English language classroom. (Unpublished doctoral dissertation). University of Exeter, Exeter, UK.

Pennycook, A. (1999). Introduction: Critical approaches to TESOL. TESOL Quarterly, 33(3), $1-20$.

Rantz, F., \& Horan, P. (2005). Exploring intercultural awareness in the primary modern language classroom: The potential of the new model of European language portfolio developed by the Irish modern languages in primary schools initiative (MLPSI). Language and Intercultural Communication, 5(3-4), 209-221. http://doi.org/10.1080/14708470508668896

Risager, K. (2007). Language and culture pedagogy. Clevedon, UK: Multilingual Matters.

Siregar, F. (2016). In pursuit of intercultural communicative competence: An investigation into English language policy and practices at a private university in Indonesia. (Unpublished doctoral dissertation). Victoria University of Wellington, Wellington, New Zealand.

Skinner, B. F. (1953). Science and human behavior. New York, NY: Simon and Schuster.

Smith, F. (1971). Understanding reading: A psycholinguistic analysis of reading and learning to read. New York, NY: Holt, Rinehart and Winston, Incorporated.

Vygotsky, L. S. (1978). Mind in society: The development of higher mental process. Cambridge, MA: Harvard University Press.

Zabetipour, M., \& Baghi, B. A. (2015). The impact of EFL teachers' years of experience on their cultural identity. Theory and Practice in Language Studies, 5(2), 330-335. http://doi.org/10.17507/tpls.0502.12 